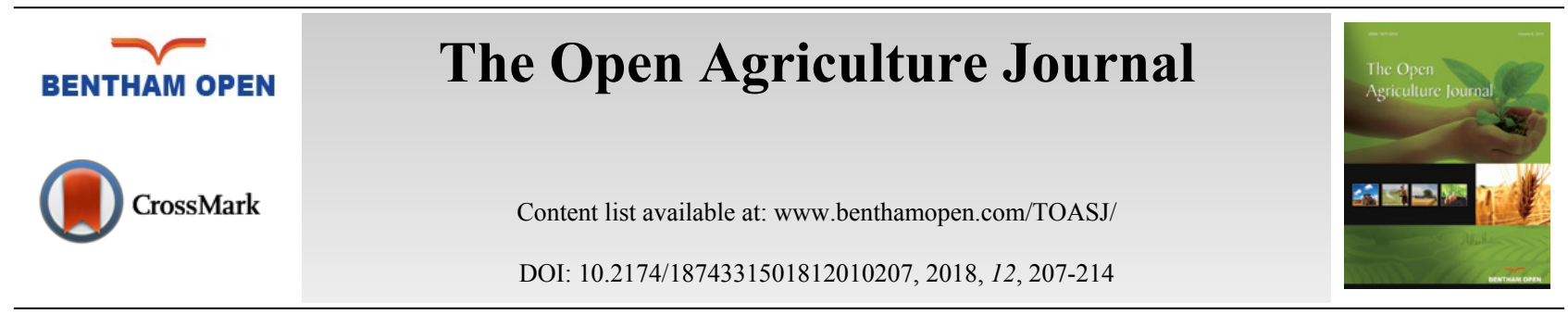

RESEARCH ARTICLE

\title{
Assessment of Soil Quality in Andosols Using Silvopastoral Systems
}

\author{
Hernán R. B. Rosales ${ }^{1}$, Silvino V. Hernández ${ }^{2, *}$, Digna I. G. Aguiar², Diego C. Rosero ${ }^{1}$, Luis C. \\ Perez ${ }^{1}$ and Marcelo I. Rosero ${ }^{1}$ \\ ${ }^{1}$ Universidad Politécnica Estatal del Carchi, Tulcán, Ecuador \\ ${ }^{2}$ Universidad Central "Marta Abreu" de Las Villas, Carretera a Camajuani km 6, Edificio C-1, Apto 110, Santa Clara, \\ Villa Clara, P.O Box. 54830, Cuba
}

Received: August 8, 2017

Revised: April 24, 2018

Accepted: September 5, 2018

\section{Abstract:}

Background:

An experiment was conducted to evaluate the effect of redesign and management upon soil quality variation using three agroecosystems: agro-ecosystem A1 (grasses, Alnus acuminata Kunth); agro-ecosystem A2 (grasses, Acacia melanoxylon R. Br.) and agro-ecosystem A3 (Rangeland).

\section{Methods:}

The trees were planted along the contour lines in December 2015. The total area was divided into three agro-ecosystems (AES). These consisted of 7.50, 4.64 and 6.25 ha managed with ten to eleven cows in A1, A2 and A3 respectively. The AES were divided into paddocks by means of electric fences. Composite soil samples were evaluated at the baseline and ten months later. Principles of rational grass management were applied with low input sustainable agriculture. The tree population density was 1000 ha $^{-1}$, planted in double rows, separated two meters apart. The genetic composition of dairy cows was 80 and $20 \%$ of Holstein and crossbreed Holstein x Jersey, respectively.

\section{Results:}

The effect of interaction between AES x year was not found. The effect of the agro-ecosystems upon the soil quality only showed significant differences $(\mathrm{p}<0.05)$ in $\mathrm{pH}(5.64,5.68,5.55)$; $\mathrm{SOM}(14.65,16.11,16.23) ; \mathrm{P}_{2} \mathrm{O}_{5}(34.67,19.50,33.48)$ and $\mathrm{K}_{2} \mathrm{O}(.16, .19$, .12) meq $100 \mathrm{~mL}^{-1}$ to $\mathrm{A} 1, \mathrm{~A} 2 \mathrm{y} \mathrm{A} 3$, respectively. On the contrary, the year's effect showed differences $(\mathrm{p}<0.05)$ on chemical variables: $\mathrm{NH}_{4}(-83.00 \mathrm{ppm})$; $\mathrm{SOM}(-1.91 \%) ; \mathrm{P}_{2} \mathrm{O}_{5}(-10.79 \mathrm{ppm}) ; \mathrm{K}_{2} \mathrm{O}(-.04)$ meq $100 \mathrm{~mL}^{-1}$ and $\mathrm{Mg}(-.42)$ meq $100 \mathrm{~mL}^{-1}$, excepted pH (.025) and $\mathrm{Ca}(1.04) \mathrm{meq} 100 \mathrm{~mL}^{-1}$ when it was compared $2015 \mathrm{vs}$. 2016. It is suggested to continue evaluating the dynamics of soil chemical variables in the subsequent two years to find out the real potential capacity of soil-plant-animal-management interactions to enhance soil quality of Andosols in dairy sector, Carchi province, Ecuador.

Keywords: Andosols, Chemical variables, Silvopastoral systems, Soil quality, Agro-ecosystem, Paddocks.

\section{INTRODUCTION}

A considerable amount of literature has demonstrated positive impact of agroforestry systems to enhance the AES resources. Nevertheless, these systems have declined in Europe in the last century, while those that maintain traditional systems are being replaced by modern agroforestry practices [1,2].

The combination of trees and crops leads to a better resources management of the agro-ecosystems, such as solar radiation and water. However, neutral and negative interactions were reported in those AES [3]. The European Union

\footnotetext{
"Address correspondence to this author at the Universidad Central "Marta Abreu" de Las Villas, Carretera a Camajuaní km 6, Edificio C-1, Apto 110, Santa Clara, Villa Clara, P.O Box. 54830, Cuba; Tel: 53 58216683; E-mail: vargas@uclv.edu.cu
} 
provided an opportunity for national and regional governments to provide financial support for the establishment of new agroforestry systems [4]. Moreover, it was discussed in the current study an innovative proposal to ameliorate the environmental degradation, enhance soil fertility and protect water resources in Carchi province, Ecuador [5].

Assessment of land degradation in Sub-Saharan Africa was evaluated by the impact of population density on different land use systems with different soil quality, affecting the sustainability and food security in African soils due to intensification processes. Some agro-ecological technologies were discussed about soil fertility management in which woody leguminous trees were used in conservation agriculture [6].

Previous studies have pointed out the effects of trees on physical and chemical soil properties, focusing on agricultural systems in Amazonia, while this review was addressed to show the effects of trees on soil physical and chemical properties in tropical, subtropical, and temperate regions, covering both natural ecosystems and agroecosystems [7].

There are multiple benefits of the Silvopastoral Systems (SPS) in the region of Latin America by combining different arrangements with improved pastures and trees for the high tropical conditions [8]. The main advantage is the significant improvement of soils and their effects on the sustainability of systems containing trees [9]. Moreover, SPS are part of traditional farming systems throughout Latin America and the Caribbean, these lead to multiple benefits that contribute to the sustainability of production systems on the basis of the synergistic interactions in crop-livestock integration [10].

The variation of some chemical indicators in different land uses and management in Colombia, indicated the highest values of Soil Organic Matter (SOM) in the agro-ecosystem Alder (Alnus acuminata Kunth) - Acacia (Acacia melanoxylon $\mathrm{R}$. Br.) and suggested that this variable is more sensitive to detect the effect of soil management. Thus, Alder is a fixing nitrogen tree through the Actinomycetes which colonizes its roots [11]. Similar benefits have Acacia but, its nitrogen fixation is through the bacteria of the genus Rhizobium [12]. An active area of research must be applied as a precondition to adopt any specific form of agroforestry understanding barriers of adoption and developing strategies to overcome these barriers [13].

Most studies in SPS have only been carried out in a small number of areas. Besides, there have been no controlled studies which compare differences in soil quality through the time using a rational grass management with an integrated approach in the province of Carchi. Ecuador. Therefore, the aim of this study was to evaluate the effect of redesign and management of SPS systems upon soil quality.

\section{MATERIALS AND METHODS}

\subsection{Location}

The study was conducted in the parish "El Carmelo", Canton Tulcán, Carchi, Ecuador. It is located in the hydrographic area 230, between $0^{\circ} 41^{\prime}$ and $3^{\prime \prime} \mathrm{N}$ and $77^{\circ} 36^{\prime}$ and $42^{\prime} \mathrm{W}$, altitude 2955 m.a.s.1 [14]. The soil is classified as Andosols, which is distinguished by a high content of Fe and Al, melanic horizon andic properties, highly humified organic matter, lower ratio of fulvic/humic acids, blackish [15]. The precipitation and temperature (Fig. 1) during 2016 were recorded [16].

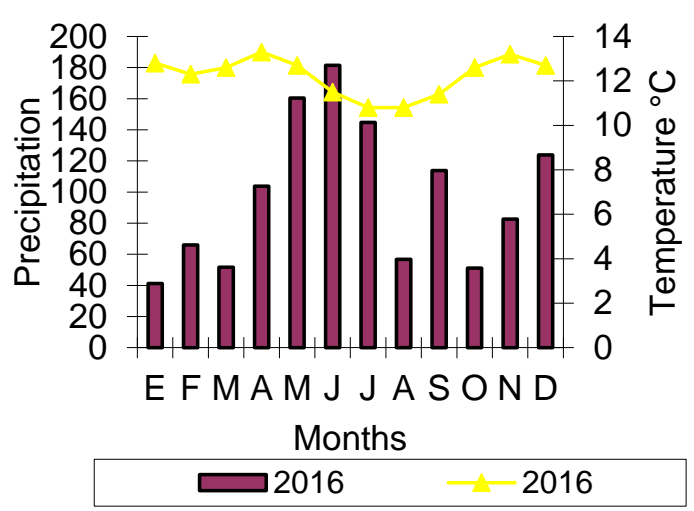

Fig. (1). Precipitation and temperature. 


\subsection{Silvopastoral Systems}

The experimental design was a completely randomized design with three AES. Two silvopastoral arrangements were used and a control experiment composed only with grasses. The predominant grasses in all AES were: Kikuyo (Pennisetum clandestinum L.), Ray grass (Lolium perenne L.), Holco (Holcus lanatus L.) and White clover (Trifolium repens L.). The AES consisted of: A1 (grasses and trees of Alder, Alnus acuminata Kunth); A2 (Grasses and acacia trees, Acacia melanoxylon) and A3 (Rangeland).

The trees were planted in December 2015. Double electric fences were established both to make paddocks and protect the young trees from animal damages. The rotation of ten to eleven cows and staying periods in the paddocks were recorded in each AES. The genetic composition of dairy cows was 80 and $20 \%$ of Holstein and crossbreed Holstein x Jersey, respectively. Rational grass management in paddocks of $1000 \mathrm{~m}^{2}$ was used. Fencing took into account the contour lines. The tree population density was $1000 \mathrm{ha}^{-1}$, planted in double rows, separated two meters apart, in A1 and A2. The area was divided into 7.50, 4.64 and 6.25 ha in A1, A2, and A3 respectively.

\subsection{Soil Sampling Process and Testing}

Field area to sample was geo-referenced with a global positioning system and sampled in the same location in subsequent years, before planting the trees, 2015 (22-11-2015) and 10 months later, 2016 (22-09-2016). An aerial photograph of the AES was shown (Fig. 2). The sampling layout was of six parallel transects. In every AES, six composite samples were collected, each sample contained 20 subsamples, taken across the slope [17], separated two meters apart from the tree rows, $20 \mathrm{~cm}$ depth. The soil samples were analyzed in the laboratories of the National Institute for Agricultural Research and in the laboratory of soil and water management belonging to "Santa Catalina" Experimental Station both in Ecuador. The chemical variables were determined by the following procedures: soil test $\mathrm{pH}$ (water, 1: 2.5); $\mathrm{NH}_{4}, \mathrm{P}_{2} \mathrm{O}_{5}, \mathrm{~K}_{2} \mathrm{O}, \mathrm{Ca}$ and $\mathrm{Mg}$ [18], and soil organic matter [19].

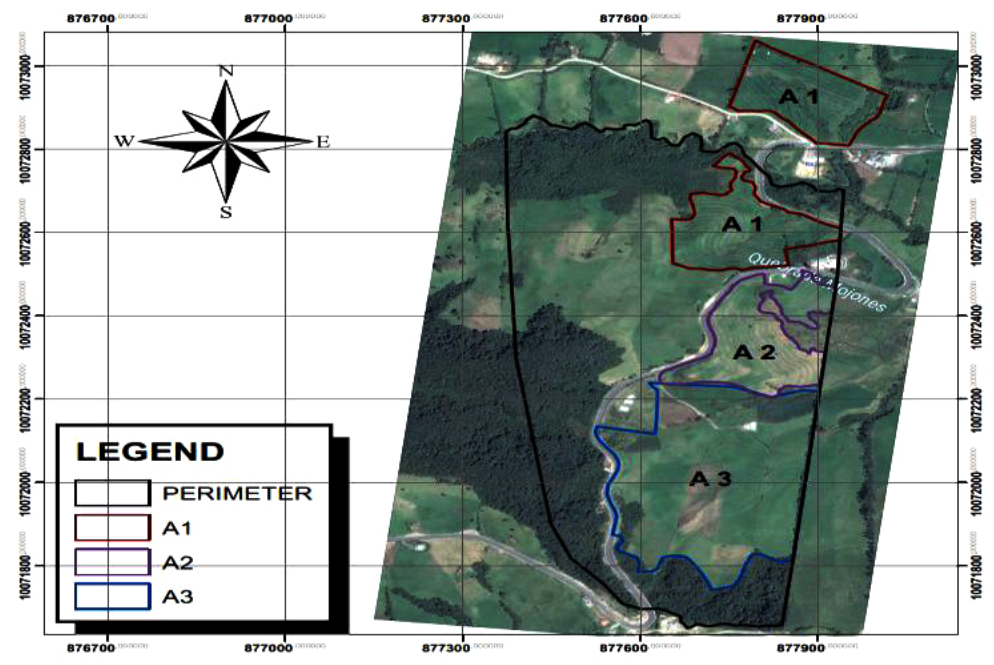

Fig. (2). Aerial photograph of the agro-ecosystems.

\subsection{Statistical Analysis}

ANOVA tests were used to analyze treatment data, using the following mathematical model, with $\mathrm{p}$ value of 0.05 . $\mathbf{Y}_{\mathrm{ijk}}=\mu+\mathrm{S}_{i}+P_{j}+(\mathrm{S}, \mathrm{P})_{\mathrm{ij}}+e_{i j k}$

Where: $Y_{i j k}$ observation corresponding to the chemical variable $\mathrm{k}$ in the agro-ecosystem $i$ and year $j$; $\mu$ : general mean of the population; $S i$ : effect of the $i$-ésimo agro-ecosystem; $P_{j}$ : effect of the $j$-ésimo year; $(\mathrm{S}, \mathrm{P})_{\mathrm{ij}}$ : effect due to the interaction of the $i$-ésimo agro-ecosystem with the $j$-ésimo year and $\mathrm{e}_{i j k}$ : experimental error. The fixed effects were the agro-ecosystem and year using the chemical variables as dependent variables. The effect of interaction between AES $\mathrm{x}$ year was not found, then both AES and year as separated effects were analyzed. A paired-samples T- Test was used to analyze the year's effect [20]. 


\section{RESULTS}

\subsection{Soil pH}

There were no significant differences $(p<0.05)$ between A1 and A2, these AES showed differences with A3 (Table 1). On the contrary, the year's effect did not show any difference (Table 2). The pH was classified as moderately acidic in A3, although in A1 and A2, pH was classified as slightly acidic. In general sense, the pH was higher in SPS compared to rangeland and the year's effect was not strong enough to produce any significant changes in $\mathrm{pH}$.

Table 1. Effect of the agro-ecosystems on the soil quality.

\begin{tabular}{|c|c|c|c|c|c|c|c|}
\hline AES & $\mathrm{pH}\left(\mathrm{H}_{2} \mathrm{O}\right)$ & $\mathrm{NH}_{4,} \mathbf{p p m}$ & SOM, \% & $\mathbf{P}_{2} \mathbf{O}_{5}, \mathbf{p p m}$ & $\mathrm{K}_{2} \mathrm{O}$, meq $100 \mathrm{~mL}^{-1}$ & Ca, meq $100 \mathrm{~mL}^{-1}$ & $\mathrm{Mg}, \mathrm{meq} 100 \mathrm{~mL}^{-1}$ \\
\hline $\mathrm{A} 1$ & $5.637^{\mathrm{a}}$ & 121.583 & $14.650^{\mathrm{b}}$ & $34.667^{\mathrm{a}}$ & $.164^{\mathrm{a}}$ & 6.658 & .737 \\
\hline A2 & $5.682^{\mathrm{a}}$ & 114.417 & $16.108^{\mathrm{a}}$ & $19.500^{\mathrm{b}}$ & $.194^{\mathrm{a}}$ & 7.708 & .700 \\
\hline A3 & $5.556^{\mathrm{b}}$ & 116.000 & $16.227^{\mathrm{a}}$ & $33.483^{\mathrm{a}}$ & $.123^{\mathrm{b}}$ & 6.967 & .617 \\
\hline $\mathrm{SE} \pm$ & .041 & 4.494 & .541 & 3.332 & .017 & .542 & .053 \\
\hline Sig. & .016 & .261 & .011 & .000 & .001 & .156 & .089 \\
\hline
\end{tabular}

$\mathrm{n}=12, \mathrm{p}<.05$, means with different superscript in the columns showed differences [38], AES: Agro-ecosystems, A1: grasses and Alnus acuminata Kunth; A2: Grasses and Acacia melanoxylon A3: Rangeland

Table 2. Effect of the year on the soil quality.

\begin{tabular}{|c|c|c|c|c|c|c|c|}
\hline Year & $\mathbf{p H}\left(\mathbf{H}_{\mathbf{2}} \mathbf{O}\right)$ & $\mathbf{N H}_{4}, \mathbf{p p m}$ & $\mathbf{S O M}, \mathbf{\%}$ & $\mathbf{P}_{\mathbf{2}} \mathbf{O}_{\mathbf{5}}, \mathbf{p p m}$ & $\mathbf{K}_{\mathbf{2}} \mathbf{O}, \mathbf{m e q} \mathbf{1 0 0} \mathbf{~ m L}^{-\mathbf{1}}$ & $\mathbf{C a}, \mathbf{~ m e q ~} \mathbf{1 0 0} \mathbf{~ m L}^{\mathbf{- 1}}$ & $\mathbf{M g}, \mathbf{m e q} \mathbf{1 0 0} \mathbf{~ m L}^{-\mathbf{1}}$ \\
\hline 2015 & 5.637 & 75.833 & 14.706 & 23.822 & 0.140 & 7.633 & 0.473 \\
\hline 2016 & 5.612 & 158.833 & 16.618 & 34.611 & 0.181 & 6.589 & 0.896 \\
\hline Mean & 0.025 & -83.000 & -1.912 & -10.789 & -0.041 & 1.044 & -0.422 \\
\hline SE \pm & 0.038 & 3.676 & 0.346 & 2.900 & 0.014 & 0.394 & 0.042 \\
\hline Sig. & .519 & .000 & .000 & .002 & .010 & .017 & .000 \\
\hline
\end{tabular}

$\mathrm{n}=18, \mathrm{p}<.05$, Paired - Samples T-Test, IBM SPSS [20]

\subsection{Soil $\mathbf{N H}_{4}$}

There were no significant differences of $(\mathrm{p}<0.05) \mathrm{NH}_{4}-\mathrm{N}$ among AES (Table 1), nevertheless it was found a difference (Table 2) between years $(-83.00 \mathrm{ppm})$. In the first and second years, ammonia nitrogen ranged from: 75.83 to $158.83 \mathrm{ppm}$, which was classified above the optimum range value [17]. The high levels of $\mathrm{NH}_{4}-\mathrm{N}$ in $\mathrm{SPS}$ and rangeland are noteworthy.

\subsection{Soil Organic Matter}

Differences were not observed $(\mathrm{p}<0.05)$ between A2 and A3 (Table 1) whereas SOM had the lowest value in A1. Also, there was a difference $(\mathrm{p}<0.05)$ in SOM between years which represents an increment of $13.06 \%$ (Table 2 ). These findings explained that the elapsed time slightly changed the SOM but the AES's effect could be explained not only as an increment of the SOM but also as its rate of production and biodegradation. All values of the SOM were classified as high [21].

\subsection{Soil Phosphate}

Significant differences of $(\mathrm{p}<0.05) \mathrm{P}_{2} \mathrm{O}_{5}$ among the AES were noticed (Table 1). A2 had the lowest value while A1 and $\mathrm{A} 3$ had the highest values of $\mathrm{P}_{2} \mathrm{O}_{5}$ but, without differences between them. The mean difference in $\mathrm{P}_{2} \mathrm{O}_{5}(-10.79$ ppm) was shown throughout the time $(\mathrm{p}<0.05)$ with $45.29 \%$ of increment (Table 2$)$. The differential impact between $\mathrm{A} 1$ and A2 could suggest an efficient mechanism to mobilize P to support the phosphorous demand on grassland production, but more time and evidence are needed to explain the differences in available phosphorous in A3 vs. A2. Generally, available P was classified as medium to high values [18] in all AES and years.

\subsection{Soil Potassium}

There were significant differences among AES $(p<0.05)$, A1 and A2 had the highest values but they did not show any difference, while $\mathrm{A} 3 \mathrm{had}$ the lowest concentration of $\mathrm{K}_{2} \mathrm{O}$ differing with all treatments (Table 1). The year's effect (Table 2) had a difference in the evaluated years $(\mathrm{P}<0.05)$. All values are ranged between deficient and critical values [18]. 


\subsection{Soil Calcium}

No differences were found (Table 1$)$ in the response variable $(\mathrm{p}<0.05)$ considering the agro-ecosystem's effect. The year's effect did not show $(\mathrm{p}<0.05)$ a significant difference (Table 2$)$. Independently of the lack of response in the variation of $\mathrm{Ca}$, this one is situated in the optimum range (4-20 meq $\left.100 \mathrm{~mL}^{-1}\right)$ [22]. All raw data in each sampling ranged from $5.96-8.40 \mathrm{meq} 100 \mathrm{~mL}^{-1}$.

\subsection{Soil Magnesium}

There were no significant differences among A1, A2 and A3 ( $<<0.05)$ (Table 1). The variation of Mg content was significant between the analyzed years (Table 2). All raw data were below the optimum range in all AES and years. It was noticeable that $\mathrm{Mg}$ content was considerably low, ranging from (0.37-0.91). The optimum values are comprised from 1-10 meq $100 \mathrm{~mL}^{-1}$ [18].

Based on our preliminary findings, the agro-ecosystem's and the year's effects did not show interactions. The impact on the response variables were demonstrated as separated effects in which both AES and years impacted the majority of chemical variables. It suggests to continue the evaluation of the dynamics of soil quality throughout the time. Thus, further data collection (at least, three years of evaluation) is required to draw a consistent recommendation of the current study.

\section{DISCUSSION}

The preliminary findings of the current study are consistent with those obtained in degraded soils in Colombia. It was demonstrated the impact of soil improvement in 13-year-old multistrata SPS on soil quality parameters. The authors stated that the effects found were associated with the tree species involved rather than the SPS arrangement [9]. On the other hand, in Amazon basin similar benefits were obtained in degraded soils using SPS [23]. The current study did not show the effect of interactions between AES and years. The analysis of AES's effect indicated significant differences $(\mathrm{p}<0.05)$ to $\mathrm{pH}, \mathrm{SOM}, \mathrm{P}_{2} \mathrm{O}_{5}$ and $\mathrm{K}_{2} \mathrm{O}$. The missing effects of interactions could be explained due to in the first three years, the fast growing trees removed part of the soil nutrient reserves and did not produce enough litter. However, once the canopy was closed (4-5 years) the trees can act as self-nourishing system via litter production and decay [24]. The historical route of $\mathrm{N}$ fertilizer applied to the soil ranged from 200-250 $\mathrm{kg} \mathrm{ha}^{-1} \mathrm{year}^{-1}$, O. Benavides in personal interview with the main author of the current study "personal communication" [25] but the residual $\mathrm{N}$ from historical fertilizer applications did not affect the current results because they occurred more than five years ago. Other important findings were that $\mathrm{Mg}$ and $\mathrm{K}_{2} \mathrm{O}$ were below their critical value INIAP [22]. These cations among others are associated with cation exchange capacity in soils, however it must be taken into account that as soils become more acidic these cations are replaced by $\mathrm{H}$ and $\mathrm{Al}$ [26]. This is particularly important in Andosols containing a high amount of $\mathrm{Al}$ [15]. The toxicity of $\mathrm{Al}$ occurs when $\mathrm{pH}$ is less than 5.5 [26] and this value is the borderline between acidic and slightly acidic soils. Therefore, further evaluation should be accomplished throughout the time to evaluate the $\mathrm{pH}$ which was one the most limiting factors in the present study. Nevertheless, the $\mathrm{pH}$ in SPS was higher than rangeland on the current study which demonstrated the beginning of the positive impact of design and management.

One of the most interesting findings was the bioavailability of $\mathrm{P}$, whose values significantly increased $(\mathrm{p}<0.05)$ from medium to high in no less than one year of running the measurements in the soil (Table 2). These results could be explained by the ability of $A$. acuminata to colonize the roots with ecto-mycorrhizal and arbuscular mycorrhizal fungi which had an impact on some soil parameters such as $\mathrm{pH}$, water holding capacity, available phosphorus, organic matter and total nitrogen [27]. Besides, a great variation of richness and composition in ecto-mycorrhizal associated with $A$. acuminata, depended on their geographical location [28]. On the other hand, the study on nutrient and mass litter in the top soil of ten tropical tree species suggested that the soil P associated with trees was on average twice that of the grasses [29]. These results were consistent with high levels of litter production in the SPS in which the P return through the litter was $1-3 \mathrm{~kg} \mathrm{ha}^{-1} \mathrm{yr}^{-1}$, while in grasses, it was only $0.2-0.8 \mathrm{~kg} \mathrm{ha}^{-1} \mathrm{yr}^{-1}$ [20]. An implication of this study is the possibility of using agroforestry as an agro-ecological technology to enhance soils quality instead of applying chemical fertilizers.

It was remarkable, that the SOM in the soil samples collected (11.90 - 18.00 to $14.60-18.80 \%)$ had very high values, from the baseline to subsequent soil samplings, respectively. The lowest value of SOM in the present study was more than twice higher than the one considered as high [30]. These values are normally found in Andosols [15]. The most likely cause of higher SOM in our study could be the amount of aluminum that protects the complex aluminum-humic 
against biodegradation. This leads to the accumulation of SOM in the soil [31]. Moreover, under plentiful vegetation a large amount of humus accumulates in the A horizon, forming the Al-humus complex in Andosols [32]. The characterization of soil and climatic conditions with the accumulation of SOM, precipitation, temperature and $\mathrm{pH}$ ranging 800-1000 $\mathrm{mm}, 10-12^{\circ} \mathrm{C}$ and $\mathrm{pH}, 5.5-6.5$ respectively, were described [12] and were similar to our research scenario. These conditions affected $\mathrm{NH}_{4}-\mathrm{N}$ concentrations at the time of sampling but did not reflect further conditions. Ammonium-nitrogen does not usually accumulate in the soil when soil temperature and moisture conditions are suitable for plant growth what facilitates the conversion of $\mathrm{NH}_{4}-\mathrm{N}$ to $\mathrm{NO}_{3}-\mathrm{N}$ [33]. Therefore, soil concentrations of $\mathrm{NO}_{3}-\mathrm{N}^{2}$ and $\mathrm{NH}_{4}-\mathrm{N}$ should be taken as a diagnostic tool or to identify trends through the time. Contrary to the expectations, a high concentration of ammonia-nitrogen will not likely increase yield because of much of that concentration is tied up in SOM and is not readily available to plants [26]. Nitrogen has to be in a mineralized form (nitrate or ammonia), it can be leached down the soil profile affecting the aquifers when availability exceeds plant nutrients demands [34]. These authors measured the impact of nitrogen fertilization on soil and aquifers in humid Pampa Argentina, in soils with 4\% of SOM and pointed out that a very significant impact on soil of three chemical $\mathrm{N}$ forms (nitrate, ammonium and urea) had a strong negative effect on abundance of $\mathrm{N}_{2}$-fixing organisms. In contrast, the current study is working with another paradigm which changes chemical fertilizers for ecological technology, which could be encouraged by $\mathrm{N}_{2}$ fixation depending on actinomycetes, colonizing A. acuminata roots and genus Rhizobium, in A. melanoxylon [11]. In this sense, leguminous trees could also transfer fixed $\mathrm{N}_{2}$ to associated grass via common mycorrhizal networks [35]. Moreover, as a consequence of the increase of the bacteria, fungi, actinomycetes and earthworms on Inceptisoil, better soil quality dynamics was achieved using L. leucocephala [30]. There was some evidence that nitrate dynamics is related to important changes in microbial activity due to: the presence of organic $\mathrm{N}$ (increase in ammonifiers) and the feed-back effect of soil nitrate (decrease of nitrifiers) [36]. The present study was limited by the elapsed time, because of soil quality dynamics must be measured during subsequent years and must be supported by soil health evidence which was observed in this scenario (unpublished data). The litter of trees, pastures, dung and urine excreted by the cows in subsequent rotations per paddocks could have increased the ammonium and nitrate in the soil [30].

The findings of this study suggest measuring the dynamics of macronutrients among soil-plant-animal to balance the recycling of nutrients like N P, K. It could be used a software to calculate the total inputs and outputs to determine the balance of those nutrients at dairy farm level [30, 37].

In general sense, the current study has important practical implications to the sustainable dairy sector, applying the agro-ecological principles of sustainable soil management to enhance soil quality in the Andean soils AES.

\section{CONCLUSION}

This study has encouraged to continue the assessment of soil quality dynamics in subsequent periods of time and years in each agro-ecosystem to demonstrate with scientific evidence the potential of agro-ecosystems' resources when a rational grass management and a good design are managed with an integrated approach. Therefore, it is recommended to continue evaluating the soil quality to support and promote SPS in this region.

\section{ETHICS APPROVAL AND CONSENT TO PARTICIPATE}

Not applicable.

\section{HUMAN AND ANIMAL RIGHTS}

No Animals/Humans were used for studies that are base of this research.

\section{CONSENT FOR PUBLICATION}

Not applicable.

\section{CONFLICT OF INTEREST}

The authors confirm that this article content has no conflict of interest.

\section{ACKNOWLEDGEMENTS}

The authors would like to thank CONDESAN "Consorcio para el Desarrollo Sostenible de la Ecorregión Andina" for facilitating the seedlings to planting Alder and Acacia. Also, the authors want to acknowledge the authorities of 
UPEC "Universidad Politécnica Estatal del Carchi” for providing necessary facilities and support to get ahead the project with alumni and some staff of EDIA Studies "Escuela de Desarrollo Integral Agropecuario".

\section{REFERENCES}

[1] Torralba M, Fagerholm N, Burgess PJ, Moreno G, Plieningerm T. Do European agroforestry systems enhance biodiversity and ecosystem services? A meta-analysis. Agric Ecosyst Environ 2016; 230: 150-61. [http://dx.doi.org/10.1016/j.agee.2016.06.002]

[2] Nerlich K, Graeff-Hönninger S, Claupein W. Agroforestry in Europe: Review of the disappearance of traditional systems and development of modern Agroforestry practices, with emphasis on experiences in Germany. Agrofor Syst 2013; 87: 475-92. [http://dx.doi.org/10.1007/s10457-012-9560-2]

[3] Rivest D, Paquette A, Moreno G, Messier C. A meta-analysis reveals mostly neutral influence of scattered trees on pasture yield along with some transplanted effects depending on functional groups and rainfall conditions. Agric Ecosyst Environ 2013; 74: 165-79. [http://dx.doi.org/10.1016/j.agee.2012.12.010]

[4] European Union. Regulation (EU) No. 1307/2013 of the European Parliament and of the Council of 17 December 2013 Establishing Rules for Direct Payments to farmers under support schemes within the framework of the Common Agricultural Policy and repealing Council Regulation (EC) No. 637/2008 and Council Regulation (EC) No. 73/2009. http:// eur-lex.europa.eu/ LexUriServ/ LexUriServ.do?uri= OJ:L:2013:347: 0608:0670:EN:PDF. Official Journal of the European Union L 2013; 347: 608-70.

[5] Franco W. Propuestas para la innovación en los sistemas agro-productivos y el desarrollo. Revista Tierra Infinita 2015 ; No. 5. (www.upec.edu.ec. UPEC, Tulcán-Ecuador). Universidad Regional Amazónica-IKIAM. https:// www.researchgate.net/ publication/ 295854413.

[6] Craswell ET. Vlek Paul. L. G. Mining of Nutrients in African Soils Due to Agricultural Intensification.Principles of Sustainable Soil Management in Agroecosystems, Advances in Soil Science. Boca Raton: CRC Press 2013; pp. 401-21.https://www.researchgate.net/publication/262014160

[7] Rachel C Pinho, Rober P. Miller, Sonia S. Alfaia. Agroforestry and the Improvement of soil fertility: A view from the Amazonia.Applied and Environmental Soil Science 2012. Article ID 616383, 11 pages http://dx.doi.org/10.1155/2012/616383.

[8] Uribe F, Zuluaga AF, Valencia Murgueitio LE, Zapata A, Solarte L. Establishment and management of silvopastoral systems. Manual 1, Colombian cattle raising project sustainable. GEF, World Bank, FEDEGAN, CIPAV, fund action, TNC. Bogota, Colombia. 2011 ; p. 78.

[9] Judith M, Judith M, Boxes YS, Leon JD, Osorio NW. Silvopastoral systems enhance soil quality in grasslands of colombia. Appl Env Soil Sci 2014; 8 pages. Article ID 359736. doi:10.1155/2014/359736.

[10] Devendra C. Perspectives on the Potential of Silvopastoral Systems. 3 Agrotechnol 2014; 117 [http://dx.doi.org/10.4172/2168-9881.1000117]

[11] Arteaga J, Navia J, Castle J. Behavior of chemical variables of a soil subjected to different uses, Nariño Department, Colombia. Rev Cienc Agr 2014; 33(2): 62-75. [http://dx.doi.org/10.22267/rcia.163302.53]

[12] Franco W, Peñafiel M, Cerón C, Freire E. Productive biodiversity and associated in the interandean valley north of the Equator. 28 Bioagro 2016; (3): 181-92.

[13] Mbow C, Noordwijk MV, Luedeling E, Neufeldt H, Minang PA, Kowero G. Agroforestry solutions to address food security and climate change challenges in Africa. Curr Opin Environ Sustain 2014; 6: 61-7. [http://dx.doi.org/10.1016/j.cosust.2013.10.014]

[14] INAMHI (National Institute of Meteorology and Hydrology). Directory Weather No. 51-2011. Quito, Ecuador. 2014. http:// www.serviciometeorologico. gob.ec/ wp-content/ uploads/ yearbooks/ weather/ Am\%202011.pdf (accessed 24 April 2017).

[15] FAO. World Reference Base for Soil Resources. update 2015 International soil classification system for naming soils and creating legends for soil maps. World Soil Resources 2014 Reports No. 106. FAO, Rome.

[16] INAMHI (National Institute of Meteorology and Hydrology). Meteorological station "Rancheros del Norte - EL CARMELO" Code, M1256 Temperatures and precipitation. Tulcan, Carchi Ecuador 2016.

[17] Taylor \& Francis Group. Soil sampling and methods of analysis. Second Edition. Canadian Society of Soil Science.Suite 300 Boca Raton: 6000 Broken Sound Parkway NW 2008. FL 33487-2742.

[18] Díaz-Romeu R, Hunter A. Soil sampling methodology, chemical analysis of soil and plant tissue and research in the greenhouse. CATIE, Turrialba, 1978; Costa Rica. 68p.

[19] Walkley A, Black IA. An examination of the Degtjareff method for determining soil organic matter and a proposed modification of the chromic acid titration method. Soil Sci 1934; 37: 29-38. [http://dx.doi.org/10.1097/00010694-193401000-00003]

[20] IBM SPSS Statistics for Windows, Version 220 Armonk. NY: IBM Corp. 2013.

[21] Molina E, Meléndez G. Tabla de interpretación de análisis de suelos Centro de Investigaciones Agronómicas, Universidad de Costa Rica. Mimeo 2002. 
[22] INIAP Análisis de la situación actual de los suelos en el Ecuador. Anexo No. 41. Quito, Octubre $2014 ; 4$.

[23] Fernandes EM, Wandelli E, Perin R, Garcia S. Restoring productivity to degraded pasture lands in the Amazon through agroforestry practices, in Biological Approaches to Sustainable Soil Systems, N. Uphoff, Ed.,pp. 305-322, CRC Press, Boca Raton, 2006 ; FL, USA.

[24] Kumar BM, Jacob S. George, Jamaludheen V. \& Suresh T. K. Comparison of biomass production, tree allometry an nutrient use efficiency of multipurpose trees grown in woodlot and silvopastoral experiments in Kerala, India. For Ecol Manage 1998; 112(1-2): 145-63. [http://dx.doi.org/10.1016/S0378-1127(98)00325-9]

[25] O. Benavides, personal communication, October 25, 2015.

[26] APAL (Australian Precision Agriculture Laboratory).. Soil Test Interpretation Guide. Agricultural Laboratory. n.d. http://www.apal.com.au/labmethods(accessed 29 junio 2017).

[27] Becerra A, Zak MR, Horton TR, Micolini J. Ectomycorrhizal and arbuscular mycorrhizal colonization of Alnus acuminata from Calilegua National Park (Argentina). Mycorrhiza 2005; 15(7): 525-31. [http://dx.doi.org/10.1007/s00572-005-0360-7] [PMID: 16034621]

[28] Kennedy PG, Garibay-Orijel R. Angeles-Arguiz, Higgins LM, R. Ectomycorrhizal fungi in Mexican Alnus forests support the host comigration hypothesis and continental-scale patterns in phylogeography. Mycorrhiza 2011; 21: 1-10. [http://dx.doi.org/10.1007/s00572-011-0366-2] [PMID: 20803040]

[29] Lugo AE, Cuevas E. Nutrients and mass in litter and top soil of ten tropical tree plantations. Plant Soil 1990; 125(2): 263-80. [http://dx.doi.org/10.1007/BF00010665]

[30] Vargas Hernández S. Production of sustainable tropical bovine milk. Design, management and evaluation of agro-ecosystems. An integrated approach. Publicia Editorial. AV Akademikerv erlag GmbH \& Co. KG Heinrich-Böcking-Str. 6-8 D - 66121 Saarbrücken. 2013; ISBN 978-3-639-55125-9. P.158.

[31] Moreno HR, Ibanez SA, Gisbert JM. Andisols. Polytechnic University of Valencia.2011. https://riunet.upv.es/ bitstream/ handle/10251/ 13676/ Andisoles.pdf?sequence=3 (Accessed 24 April 2017).

[32] Status of the World's Soil Resources (SWSR) - Main Report. Rome, Italy: Food and Agriculture Organization of the United Nations and Intergovernmental Technical Panel on Soils 2015; p. 648.

[33] Horneck DA, Sullivan DM, Owen JS, Hart JM. Soil Test Interpretation Guide 2011. https://catalog.extension.oregonstate.edu/ec1478 .(Accessed 20 June 2017).

[34] Abril A, Roca L. Impact of nitrogen fertilization on soil and aquifers in the humid pampa, argentina. Open Agric J 2008; 2 : $22-7$. [http://dx.doi.org/10.2174/1874331500802010022]

[35] Li YJ, Liu ZL, He XY, Tian CJ. Nitrogen metabolism and translocation in arbuscular mycorrhizal symbiote and its ecological implications. Ying Yong Sheng Tai Xue Bao 2013; 24(3): 861-8. [PMID: 23755506]

[36] Tebbe CC, Schloter M. Biodiversity in Agricultural Production Systems Discerning the diversity of soil prokaryotes (bacteria and archaea) and their impact on agriculture, CRC Taylor \& Francis, Boca Raton. FL 2007; pp. 81-100.

[37] Rodriguez I, Crespo G, Fraga S. Application of the software recycling of nutrients in cattle units of the western part of Cuba. Can J Agric Sci 2005; 39: 615 .

[38] Tukey JW. Comparing individual means in the analysis of variance. Biometrics 1949; 5(2): 99-114. [http://dx.doi.org/10.2307/3001913] [PMID: 18151955]

(C) 2018 Rosales et al.

This is an open access article distributed under the terms of the Creative Commons Attribution 4.0 International Public License (CC-BY 4.0), a copy of which is available at: (https://creativecommons.org/licenses/by/4.0/legalcode). This license permits unrestricted use, distribution, and reproduction in any medium, provided the original author and source are credited. 